\title{
Tax Audit Performance in Ethiopia: The Case of Western Addis Ababa Small Taxpayer Branch office
}

\author{
Tesema Gemeda \\ Addis Ababa Revenue Authority \\ Teklu Kassu(PhD) \\ Ethiopian Civil Service University
}

DOI: $10.7176 / \mathrm{JESD} / 11-19-06$

Publication date:June 30th 2020

\section{Introduction}

A tax is a compulsory levy by government through its agencies on personal income, business profits, consumption, and capital of its citizens to generating revenue for government to furnish for its expenditure (World Bank, 2011). Taxation system is as old as the world itself and Tax audit has been known since the biblical era (Nwaiwu and Macgregor, 2018). Tax audits are for the most part used to detect and redress taxpayers' noncompliance and increase future compliance. An effective and efficient audit strategy is mainly based on training and incentive programs for tax auditors, the performance of information technology (IT), and adequacy of the legal framework for audits, applying appropriate case selection methodology (World bank, 2011; Marshall and Pomeranz, 2013).

Tax audit is among the most effective deterrence measures in raising additional revenue, increasing tax compliance and, lowering future noncompliance. Effective tax audit practice selects tax audit cases based on their associated risks and for the selected taxpayers the tax auditor could apply various techniques and procedures depending on the area of risk and the circumstances of the particular taxpayer (World Bank, 2011; ERCA, 2010; Ethiopian Ministry of Revenue, now after MoR, 2019). Despite the many strategies practiced by tax organizations in developing countries, the failure to collect the potential tax revenue is persisting and, the tax-to-GDP ratio is lower than their target (Bird, 2008; African Economic Outlook, now after, AEO, 2019).

The developed countries also loses some amount of money due to tax evasion as the study of Murphy (2012) indicated lose of 864 billion Euros in annual tax revenues to tax evasion in the 28 member states of the European Union. Even though the Government revenue was increased from $\mathrm{Br} 30 \mathrm{bn}$ ten years ago to $\mathrm{Br} 270 \mathrm{bn}$ in 2017/18 (Cephus, 2019), the country is losing around 10 percent of its GDP in tax evasion (Asaminew, 2010). Another study showed that Ethiopia has lost at least 3.2 billion USD in 2014 that should have been collected from taxes, due to tax evasions and other factors (UNDP, 2016). Ethiopia's revenue-to-GDP is $12.2 \%$ (for FY 2017-18) that is low in a cross-country context and remains untouched (Neway et al, 2018). The study of Muhammad (2013) indicated audit collection contributes $3.6 \%$ to total net direct tax collection each year that makes audit programs an important tool for securing government revenue.

Ethiopia was implanted tax audit practice following the economic shift from command economy to free market economy in 1994. However, tax audit practice in Ethiopia has been challenged by many factors and indicating poor performances in terms of audit coverage, revenue yield and other qualitative measures. The main contributing factors are lack of competent audit staff, low data quality, ineffective risk selection practices, ineffective audit techniques, negative attitude towards taxpaying practices among taxpayers, low incentives for compliant taxpayers and tax auditors laws (Getaneh, 2011; Netsanet and Chinniah, 2014; Mekonen, 2017). Other studies also revealed inconsistency and frequent changes of tax laws, low intelligence inputs, low knowledge among taxpayers and tax auditors (Belay, 2018; Tesfaye, 2018, Solomon, 2019). Further, studies show up to 80 percent of all tax adjustments were contested by taxpayers due to reasons ranged from taxpayers low tax awareness to the most complex questions of legal principle (Muhammad, 2013).

In the last decade, tax audit has been a critical issue often discussed in Ethiopia. However, as far as the researcher's knowledge is concerned, there was no study conducted on risk based tax audit practice and its performance in Ethiopia, specifically the study area. Further, none of the studies has examined tax audit performance in terms of tax appeal decisions. This research is undertaken to evaluate tax audit performance in terms of tax yield, audit coverage and, audit quality; and suggest remedial measures to improve the performance of the tax audit practiced.

\section{LITERATURE REVIEW}

Most revenue organizations of the world rely on taxpayers' self-assessment system. However, unless systematically administered such system of self-assessment has inherent risks to the revenue administration and the whole economy. The European Commission (2010) defines risk as anything negative that can affect the organization's ability to achieve its objectives. Tax authorities should manage these potential risks by balancing 
the resources and structuring the range of audit products accordingly to ensure that people meet their obligations through education, quality and fair audit service and support, and enforcement in a way that is acceptable to the community and sustainable in the long term. To make audit more efficient and effective and to maximize resources, audit selection based on establish risk criteria will be used to select a particular taxpayer for a mandatory audit (ERCA, 2010).

Effective tax audit program provides valuable support in gathering information on the health of the tax system, improving future compliance, and identifying areas of the tax law that require clarification (Sarfo, 2015). When tax audit practice becomes ineffective, it may result in the deterioration of tax compliance and a loss of credibility of the tax administration (Tesfaye, 2018). Audit effectiveness starts at selecting the high-risk taxpayers for audit and ends at rising taxpayer's compliance. The common audit case selection methods include random selection of cases, manual screening/case review by auditors, and risk based case selection (World Bank, 2011). Even though risk based case selection is cost effective and increasingly used by revenue offices, the effectiveness of case selection depends largely on the level of computerization and information technology (IT).

Tax administration should be effective in the sense of ensuring high compliance by taxpayers, and efficient in the sense that administrative costs are low relative to revenue collected. Good tax administration requires strong technical capacity by the administrative agency but also a well-designed tax (Thomson, 2008). an effective tax audit is one that can improve deterrence measures by increasing the probability of being detection, rather than imposing sanctions. According to Tax audit manual of MoR (2019) audit performance evaluation should consider: Audit quality, Audit yield and Audit coverage.

A good audit program employs strategies to optimize both the direct and the deterrent effects of audits (Biber, 2010). Voluntary compliance is generally enhanced by increasing the number of taxpayers audited than by auditing fewer taxpayers with large tax potential. Perversely, revenue is increased by concentrating on those taxpayers where a large amount of revenue is at risk. But there should be a careful planning when there is a widespread belief that most tax returns are underreported, otherwise there may be an over selection of returns for audit (Tait 1988).

Today's tax agencies typically lose some percentage of total revenues due to tax evasion and other types of noncompliance known as the "tax gap" (Brown \& Mazur, 2003). Instances of failure to comply with the law are inevitable whether due to taxpayers' ignorance, carelessness, recklessness and deliberate evasion, or weaknesses in administration (MoR, 2019).

Finally, when tax audit is well conducted, taxpayers understand that their returns will be quickly and scientifically analyzed, voluntary compliance rates may rise which could help tax agencies avoid costs and further improve revenue collections (Nwaiwu and Macgregor, 2018).

Okonkwo (2014) identified cause of tax appeal as Poor/lack of record keeping by Taxpayers; Lack of cooperation by taxpayers and Agents; Partial submission of books and records for inspection; deliberate introduction of delays; Aggression; Reconciliation meetings not taken seriously; Lack of audit skills by some Tax Auditors leading to prolonged reconciliation meetings; and Inducement of tax auditors. The ATO (2006) reported that many cases brought to litigation were due to tax officers' failure to identify the relevant facts, failure to reference identified facts as evidence, not gathering appropriate evidence, making inappropriate assumptions and assertions in audit and objection decisions and not obtaining relevant facts and information.

The MoR audit manual (2019) defines audit quality in terms of occasional Audit reviews by internal audit and taxpayers' objections to the tax audit assessments. According to the manual audit quality may be measured as a proportion of comprehensive audit appeal cases concluded in the favor of the Ministry. The revenue office has enacted different stages of appeal resolution starting from tax appeal office in the branch up to the highest court in the country (MoR, 2019). The grounds for appeal before the independent review team within the Ministry of Revenues (MOR) may be on issues of fact or a question of law or both. This is unlike an appeal before the Federal High Court which is strictly on a question of law only.

\section{Research Methodology}

This study adopted a descriptive survey. The study has employed a mixed approach to counter-balance the limitations of one approach with the strengths of the other and enhance reliability of the results. The population consists of all the 62 risk based tax auditors and 10 team leaders. Since the target population is small in number the collection cost would be minimum and the researcher chose the census method for data collection than sampling technique. Data was collected using semi-structured questionnaire that was administered to risk based tax auditors and a face-to-face interview to the risk based audit team leaders. Secondary data were obtained from tax department and the branch's annual performance reports, various books, articles, and research journal. Further, twenty-five risks based tax audit cases were selected by multi stage sampling from the recent five years (2014/152018/19) tax audit reports. The collected data were analyzed through descriptive statistics, and presented through Percentages, standard deviations, average, tables, and graphs. 


\section{Results and Discussion}

The main aim of the study was to assess risk based tax audit practice and its performance. From the total 59 Questionnaires distributed to risk based tax auditors, the response rate $88 \%$ was reasonably good for developing countries like Ethiopia (Yesegat, 2008). Of the ten risk based tax audit team leaders, eight were interviewed and one hundred thirty five tax audit reports were included for analysis. Tax audit performance is mainly measured in terms of audit quality, revenue yield and, audit coverage (OECD, 2004; MoR, 2019).

\subsection{Tax Audit Qualitative Performance}

The key principles that apply to quality audits are objective in making decisions based on facts, transparent in documenting the work papers and discussion with the taxpayer, fair being technically accurate and procedurally, complete in having defined start and end point (OECD, 2006). On the other hand the recent Ethiopian Ministry of Revenue tax audit manual (MoR, 2019) sets pattern to measure tax audit performance in terms of audit quality (number decisions in favor of the tax office during tax appeal process), revenue yield (additional revenue assessed), and audit coverage though revenue yield is not universally used as a tax audit performance indicator (OECD, 2004). Table 4.1: Qualitative measures of tax audit performance

\begin{tabular}{|c|c|c|c|c|c|c|c|}
\hline $\begin{array}{l}\mathrm{N} \\
\mathrm{O}\end{array}$ & $\begin{array}{l}\text { Evaluate the tax audit performance of the } \\
\text { branch in terms of }\end{array}$ & $\begin{array}{l}\text { I can't } \\
\text { evaluate } \\
\text { (1) }\end{array}$ & $\begin{array}{l}\text { Weak } \\
(2)\end{array}$ & $\begin{array}{l}\text { Moderat } \\
\text { ely } \\
\text { effectiv } \\
\text { e } \\
(3)\end{array}$ & $\begin{array}{l}\text { Effectiv } \\
\mathrm{e}(4)\end{array}$ & $\begin{array}{l}\text { Me } \\
\text { an }\end{array}$ & $\begin{array}{l}\text { Standa } \\
\text { rd } \\
\text { Deviati } \\
\text { on }\end{array}$ \\
\hline 1 & $\begin{array}{l}\text { Performing tax audit according to tax audit } \\
\text { manual }\end{array}$ & 7.80 & 48.1 & 23.50 & 21.6 & $\begin{array}{r}2.5 \\
8 \\
\end{array}$ & 0.92 \\
\hline 2 & $\begin{array}{l}\text { Assigning appropriate tax auditor and time } \\
\text { based on complexity of the case and/or risk } \\
\text { level }\end{array}$ & 13.50 & 57.70 & 21.20 & 7.70 & $\begin{array}{r}2.2 \\
3 \\
\end{array}$ & 0.78 \\
\hline 3 & $\begin{array}{l}\text { Detecting noncompliance behavior of the } \\
\text { taxpayers }\end{array}$ & 7.70 & 44.20 & 40.40 & 7.70 & $\begin{array}{r}2.4 \\
8\end{array}$ & 0.75 \\
\hline 4 & $\begin{array}{l}\text { Producing transparent audit procedures and } \\
\text { audit decisions. }\end{array}$ & 3.90 & 39.20 & 45.10 & 11.80 & $\begin{array}{r}2.6 \\
5 \\
\end{array}$ & 0.74 \\
\hline 5 & $\begin{array}{l}\text { Creating audit reports that are clear and based } \\
\text { on tax laws }\end{array}$ & - & 30.80 & 50.00 & 19.20 & $\begin{array}{r}2.8 \\
8\end{array}$ & 0.70 \\
\hline & Cumulative Average & 6.58 & 44 & 36.04 & 13.6 & $\begin{array}{r}2.5 \\
6 \\
\end{array}$ & 0.78 \\
\hline
\end{tabular}

Source: Filed survey, 2020

Efficient and effective tax audit practice not only need professional and educated persons but also needs audit support tools like tax audit manual. According to most (48.1\%) respondents, the branch is ineffective in conducting audits as per the audit manual standards (mean $=2.58, \mathrm{SD}=0.92)$. Besides, majority $(57.7 \%)$ of the respondents believe the branch was poor in assigning appropriate tax auditor and time based on complexity and/or risk level of the audit cases (mean=2.23, $\mathrm{SD}=0.78$ ). The interview result with team leaders also showed, "equal time is allotted for all taxpayers without considering the size, risk level, sector of the taxpayer and...inadequate time was assigned to conduct effective tax audit implies low likelihood of detecting non compliant taxpayers." Furthermore, there is no transparent file assignment system and standard in the branch office and "tax audit team leaders can make prejudice to benefit some tax auditors by assigning simple and potential files." The findings are similar to Solomon (2019) and Kidist (2016) that concluded equal time is assigned for audit files without considering their business sector and complexity.

Most of the respondents believed that the branch has weak performance in detecting the non-compliance behavior of the auditee's $(44.2 \%$, mean $=2.48, \mathrm{SD}=0.75)$. As studies showed a strong association between probability of audit detection and the level of tax compliance (Drogalas and Dimitra, 2015), the branch should enhance the tax audits level of detection. According to the interview the low detection of the audit system was mainly due to failure in selecting taxpayers who are intentionally avoiding their tax obligations, low third party data, little invoice matching mechanisms, ineffective law enforcement including cash register and intelligence. About Producing transparent audit procedures and audit decisions, most $(45.1 \%)$ of the respondents evaluated the tax audit performance as moderately effective, while 39.2\% evaluated as weak performance with mean 2.65 and standard deviation 0.74 . This means the tax auditors should work on creating more transparency in audit process.

Further, the auditors ability to properly communicate the audit findings of audits was another indication for audit quality though majority of the respondents replied that audit reports are not clear and based on tax laws $(61.5 \%$, mean $=3.73, \mathrm{SD}=0.99)$. The interview result complemented the result stating "some auditor's audit report was just statements like 'rent expense was rejected due to lack of supporting documents, accommodation expense was rejected because it is disallowed by law...without referencing to tax laws and clear explanations." In general, 
the overall mean was above average (2.56) meaning the branch has moderate performance that makes the findings in-line with Kidist (2016) and different from Belay (2018).

Despite the fact that measuring audits quality can be very problematic due to its subjectivity in nature; the review process by an independent office within the tax body can be used to validate the quality of audits executed by the tax audit teams (MoR, 2019). That means audit quality could be measured as a proportion of appeal cases concluded in the favor of the tax audit department among the comprehensive audit assessments objected. Consequently, during the 2014/15 budget year, the western A/A/S/T/P/B office completed 549 comprehensive audit cases out of which majority $(51 \%)$ were objected the tax audit assessments and reviewed by the independent tax appeal resolution office in the branch and forty-six percent were concluded in favor of the tax office. Arising from the above statements, the quality of the audits practiced in percentage terms was $72.91 \%(49.36 \%+50.64 \%$ $\mathrm{x} 46.50 \%$ ) in 2014/15 budget year. The audit quality has shown marvelous increment in 2018/19 budget year to $96.36 \%(89.15 \%+10.85 \% \times 66.43 \%)$ as shown in the graph below.

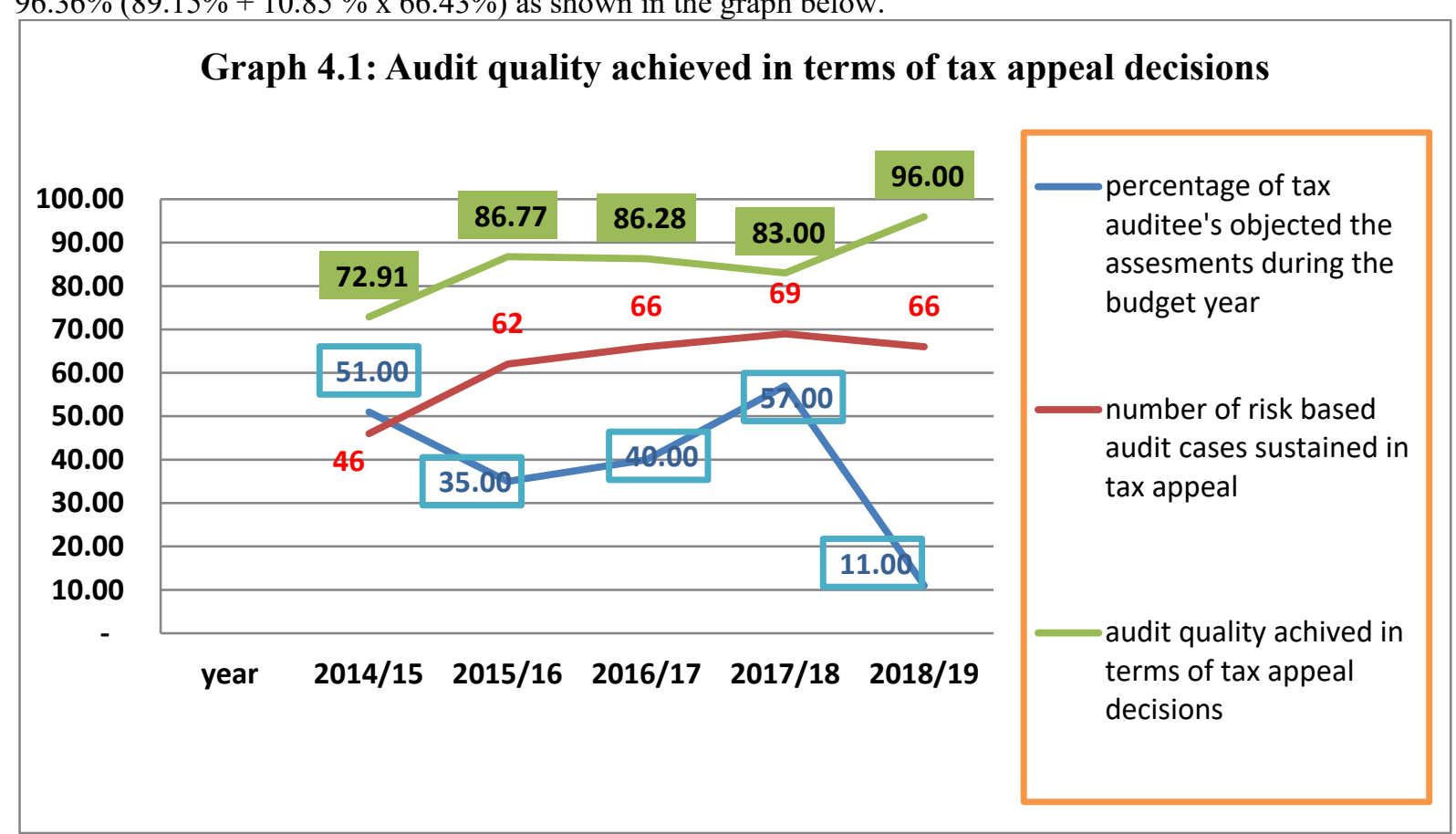

Source: compiled by the researcher from audit reports, 2020(see appendix A).

Ligomeka(2019) in his recent study that assessed the performance of Malawian tax administration concluded that majority of taxpayers do not know the option to take tax disputes to court or to a special arbitrator within the set date. Cases concluded in favor of tax office does not show the absolute quality since some taxpayers proceed to the further process (appeal commission to Federal Supreme Court) and the decision of the tax appeal office could be revised. For example, the 2017/18 annual performance report of the Federal Ministry of Revenue shows among the taxpayers that pressed their appeal to court; 176 cases were concluded in favor of the revenue office and 66 for tax payers, though data was not available for tax appeal commission cases. Furthermore, failing to file objection for appeal does not mean the audit assessment was right since some tax payers doubts the independence of the appeal system and others does not know the appeal process; and most tax payers might have no access to specialized tax advice (tax agents, authorized external auditors); and lawyers who are aware of the tax laws and dispute resolution process.

\subsubsection{Tax audit yield performance}

Another measure of tax audit performance has been the tax auditor's ability to assess additional tax revenue and the share of the tax audit to the branch's annual revenue collection as shown in the graph 4.4 below. 


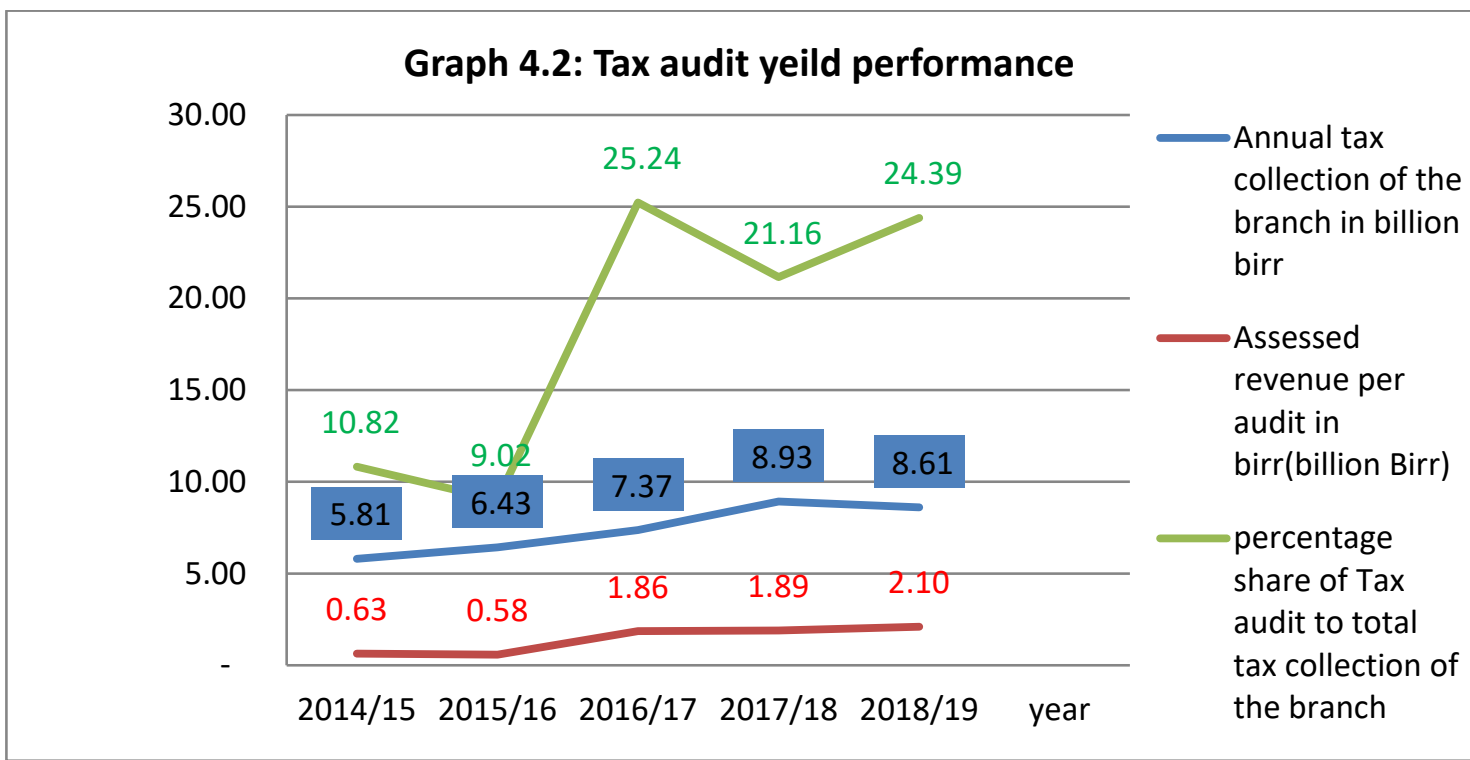

Source: compiled by the researcher from annual performance reports of the branch, 2020

As it can easily seen from graph 4.4 above, in the 2014/15 budget year the branch have collected 5.81 billion birr, 6.43 billion birr in 2008, 7.37 billion birr in 2016/17, 8.93 billion birr in 2017/18, and 8.61 billion birr in $2018 / 19$ budget years. The branch's collection performance has shown increments from year to year except the year 2018/19 that indicates 32 million (4\%) under performance of the prior year. In the 2018/19 budget year, the branch have planned to collect birr 9.47 billion but collected 8.61 Billion birr which is $91 \%$ of the plan and 852.30 uncollected taxes. According to the annual performance report of the branch the main reason for underperformance in the budget year was the tax payer segmentation that made potential taxpayers transfer to the medium taxpayer's office (MTO) and large taxpayer's office (LTO). The branch office was medium taxpayers office until the year 2018/19 and medium taxpayers was established which resulted in the branch office to become small taxpayers office. The tax audit share from total tax revenue collected in the branch office in the last five years was $18.3 \%$ on average indicating the increasing role of tax audit in the performance of tax revenue collection in the branch office.

The revenue assessed by tax audit showed tremendous increment from br. 0.63 billion to br. 2.10 billion birr in 2018/19 budget year. There was no assessed compliance level achieved through tax audit. This indicated tax compliance gets less attention than tax revenue collection which is in line with tax audit practice at Adama Revenue and Customs office (Belay, 2018). However, international experience suggests that evaluating tax auditors and/or the branch office by the additional assessments they raised should result in strongly biased tax audits against taxpayers (OECD, 2004). The percentage share of tax audit practice to the total tax collection of the branch office was increased from $10.82 \%$ in $2014 / 15$ fiscal year to $24.39 \%$ in $2018 / 19$ that is much far than that of study of Muhammad(2013).

\subsubsection{Audit coverage achieved}

Fairly well established and effective tax audit program should broadly cover all taxpayer groups (by size and sector) and compliance issues (Harrison and Krelove, 2005) with audit coverage rate of 15 to 20 percent of registered traders a year (Tait, 1988). However, the document review showed that audit coverage of the branch office for the year $2014 / 15-2018 / 19$ was $9.87 \%$ on average that is below the international benchmarks. However, the audit coverage has been increasing from year to year justified by the increment from $7.83 \%$ in $2014 / 15$ to $15.15 \%$ in 2018/19 budget year.

Table 4.2: Tax audit coverage achieved

\begin{tabular}{|c|c|c|c|c|}
\hline Year & $\begin{array}{c}\text { Total Number of tax } \\
\text { payers in the branch } \\
\text { office }\end{array}$ & $\begin{array}{c}\text { Comprehensive tax } \\
\text { audit performed in } \\
\text { budget year }\end{array}$ & $\begin{array}{c}\text { Tax Audit } \\
\text { coverage } \\
\text { achieved in \% }\end{array}$ & $\begin{array}{c}\text { Comprehensive audit } \\
\text { performance } \\
\text { Annual Increment }\end{array}$ \\
\hline $2014 / 15$ & 7,014 & 549 & 7.83 & - \\
\hline $2015 / 16$ & 8,408 & 713 & 8.48 & 29.87 \\
\hline $2016 / 17$ & 9,922 & 836 & 8.43 & 17.25 \\
\hline $2017 / 18$ & 11,033 & 1042 & 9.44 & 24.64 \\
\hline $2018 / 19$ & 12,840 & 1945 & 15.15 & 86.66 \\
\hline Average & 9,843 & 1017 & 9.87 & 31.68 \\
\hline
\end{tabular}

Source: compiled by the researcher from annual performance reports of the branch, 2020

As described in table 4.2 above, the numbers of taxpayer were incremented from year to year similar to the 
tax payers audited. The tax audit coverage has been increasing from year to year except the year 2016/17 and hard to believe increment was shown in 2018/19 budget year. The remarkable increment in 2018/19 was mainly due to the branch becoming small taxpayers' branch office in which tax auditors are expected to audit two cases per month, in addition to tax reforms. Even if the audit coverage was shown decrement; the revenue assessed by tax audit have tripled from br. 0.58 billion in $2015 / 16$ to br. 1.86 billion in $2016 / 17$ budget year indicating improper work plan and auditors focus on revenue assessment than audit coverage achievement. It seems, the plan was based on 2015/16 annual performance (that was 5 million birr below the 2014/15 performance), without considering other factors (Graph 4.2 above).

\section{Conclusion}

This paper was attempted to examine the risk based tax audit performance in terms of quality and quantity. These investigations were addressed by employing self-administered questionnaires, semi structured interview and, reviewing audit reports and annual performance reports for the year 2014/15-2018/19.

The study findings shows that most audit cases was not conducted as per audit manual and weak performance in detecting non-compliant taxpayers. Giving equal 15 days per audit cases regardless of the complexity of audit cases, business turnover, business sector, and risk level might result operational inefficiency including low detection, low audit quality, low audit coverage and weak revenue yield. Further tax auditors give less attention for auditee's awareness creation during the audit process and tax auditor's professional advice and recommendations was not given in written form for the taxpayers.

The audit quality in percentage terms of tax audit appeal decisions was 72.91\% in 2014/15 budget years and shown marvelous increment in 2011-budget year to $96.36 \%$. However, failing to file objection for appeal does not ensures the audit assessment was ultimately right. The branch has good performance in terms of tax audit coverage. The document review showed that audit coverage of the branch office for the year 2014/15-2018/19 was $9.87 \%$ on average that is below the international benchmarks (15-20\%). yet, the audit coverage has been increasing from year to year as justified by the increment from $7.83 \%$ in $2014 / 15$ to $15.15 \%$ in $2018 / 19$ budget year. The audit quality of the branch office has shown good performance and the taxpayers objecting the audit assessments are decreased due to many reasons.

\section{Recommendations}

1. To properly detect noncompliance and achieve the required audit quality the branch office should revise the stated 15 days audit period with the consideration of the complexity of the cases, business turnover, business sector, and the risk level of the taxpayer. Further, there should be strong follow up mechanism and tax audit team leaders capacity buildings to accomplish audits at best attainable time.

2. Having inadequate audit resources, the spot (issue) audit should be widely applied to increase the audit coverage, and education type audits should be implemented to improve taxpayers' awareness.

3. Besides the tax audit, Ministry of Revenue should apply other tax audit supportive methods that could enable government employees to credit some proportion of their purchases through cash register machines against their personal income tax, apply VAT-Lottery methods, and strengthening other intelligence and law enforcement mechanisms, specifically cash register sales machine supervisions.

4. To reduce the number of taxpayers filling appeal, educational programs should be enhanced and there should be a precondition to restrict tax auditees from appeal. Trainings should be given for auditors regarding the issues leading to appeal, and the legal directorate should provide adequate feedback on court and appeal commission cases; appeals and the objection decisions made thereof should be a source of knowledge to the audit teams to improve their approach to audit assignments.

5. Further, the branch office should examine the issues concerning whose audit cases are mostly objected by taxpayers, the team leader's comment on the exit meeting format, whether the concerned bodies attended the exit meeting and if not why, what issues the taxpayer raised on exit meeting to identify the core problems and take necessary action. Tax auditors should be evaluated by tax assessments after appeal. At the end, the study recommends, complex laws should be amended and those directives and circulars leading for tax appeal should be revised.

6. To overcome the major challenges and enhance the risk based tax audit performance, a template containing what the taxpayer benefits by being audited, the rights and responsibilities of the taxpayer and the tax auditor (summarized one to two pages) should be given for auditee's during entry meetings to revolutionize taxpayer attitude towards tax audit and provide timely response for the audit process

\subsection{Future Research Implications}

The study was a case study of $\mathrm{W} / \mathrm{A} / \mathrm{A} / \mathrm{S} / \mathrm{T} / \mathrm{P} / \mathrm{B} / \mathrm{O}$, and the results will have important implications and is believed to be helpful for the branch office and for the Ministry of revenue. Even though this study has revealed some interesting results, one should be careful of its limitations related essentially to its sample size and scope of the 
study. Although the researcher believes that this study is deep, it is still believed that it can be further extended to include more respondents from taxpayers, tax agents, and external tax auditors to make it more realistic and more reliable. It is also recommended that further research be undertaken in the area by including more sample and more documentary analysis to deal with core causes for tax appeal and make the risk based tax audit more effective.

\section{References}

African Economic Outlook (AEO, 2019), Macroeconomic performance and prospects: African Development Bank. Australian Taxation Office (ATO) 2006, Review of Tax Office management of Part IVC litigation: a report to the Minister for Revenue and Assistant Treasurer, ATO, Canberra.

Belay T.(2018), Assessment of Tax Audit Practice and It's Challenges: The Case of Adama Revenues And Customs Office: Master's Thesis, St. Mary's University.A.A, Ethiopia.

Bird, Richard M. (2008).Tax Challenges Facing Developing Countries"e, Working Paper Series, IIB Paper No. 12 , Institute for International Business, Rodman School of Management, University of Toronto.

Brown \& Mazur (2003). IRS Comprehensive Approach to Compliance Measurement African Journal of Business \& Management Vol. 1 pp .233-856

Clement et al.(2018), Tax audit and tax productivity in Lagos state, Nigeria, Department of Accounting, Faculty of Management Sciences, Ekiti State University, Ado-Ekiti, Nigeria, www.emeraldinsight.com/24434175.htm.

Drogalas, Ioannis, Dimitra and Ioannis (2015), Tax audit effectiveness in Greek firms: Tax auditors perceptions, Journal of Accounting and Taxation, http://www.academicjournals.org/JAT, Vol. 7(7), pp. 123-130.

Ephrem D. (2017).Tax Audit Practice in Ethiopia; Case of Federal Government. A Master's Thesis, St. Mary's University, A.A, Ethiopia.

ERCA (2010).Tax and PCA Audit Policy and Strategy, unpublished.

Ethiopian Ministry of Revenue (MoR, 2019), Tax Audit Manual (unpublished).

Getaneh, M. (2011).Tax Audit Practice in Ethiopia; Case of Federal Government.Thesis, Addis Ababa University: Addis Ababa, Ethiopia.

Harrison G. and Krelove R. (2005) VAT refunds: A review of country experiencee, (Statement on Auditing Standards) No.105

Kidist, T. (2016), Tax Audit Practice in Ethiopian Revenue and Customs Authority: Case of Addis Ketema Sub City.A Maters Thesis, St. Mary's University, Addis Ababa, Ethiopia.

Ligomeka W. (2019). Assessing the Performance of African Tax Administrations: A Malawian Puzzle, African Tax Administration Paper 14, the International Centre for Tax and Development at the Institute of Development Studies, Brighton BN1 9RE, UK

Marshall, C. and Pomeranz,D(2013), Randomized Tax Enforcement Messages A Policy Tool for Improving Audit Strategies.

Mekonnen B. (2017), Challenges of Tax Audit Administration in Addis Ababa: evidence from Small Tax payer Branches; Addis Ababa: Master's Thesis, St. Mary’s University, Addis Ababa, Ethiopia.

Muhammad, Izlawanie(2013). Managing Mixed Responsibilities: A Grounded Theory of Malaysian Tax Auditors' Dispute Resolution Behavior in Audit Settlement: A Thesis in Fulfillment of The Requirements For the Degree of Doctor of Philosophy, School of Taxation And Business Law, The University of New South Wales, Australia.

Murphy, R. (2012), Closing the European Tax Gap: A report for Group of the Progressive Alliance of Socialists \& Democrats in the European Parliament, Norfolk: Tax Research LLP.

Neway, Gobachew, Kenenisa, L. Debela and Woldemicael, Shibiru( 2018). Determinants of Tax Revenue in Ethiopia. Economics. Vol. 6, No. 1, 2018, pp. 58-64. doi: 10.11648/j.eco.20170606.11,http://www.sciencepublishinggroup.com/j/eco.

Netsanet B. and Chimelah A. (2014). Assessment of tax audit practice: the case of Hawassa city administration. IFSMRC international publications (pvt, Volume 4, Issue8.

Nwaiwu and Macgregor (2018), Webometric Indices of Tax Audit and Tax Revenue Generation Research in Nigeria: International Journal of Advanced Academic Research, social \&Management Sciences, ISSN: 24889849Vol. 4, Issue 2.

OECD (2004), Compliance Risk Management: Audit Case Selection Method, Information Notes, October 2004, Tax Administration Compliance Sub-group, available at, $<$ http://www.oecd.org/dataoecd/44/36/33818568.pdf>, accessed on March 2020.

OECD (2006), Strengthening Tax Audit Capabilities: General Principles and Approaches, Information note, October 2006, Tax Administration Compliance Sub-group, available at $<$ http://www.oecd.org/dataoecd/46/18/37589900.pdf>, accessed on March 2020

Sarfo, Opoku Joseph 2015, The Role of Tax Audit in Revenue Mobilization in Ghana Revenue Authority: The Case Of Ashanti Region. A thesis Submitted to the Department of Accounting and Finance, Kwame Nkrumah 
University of Science and Technology (KNUST)

Solomon S. (2019), Perception of Tax Audit Practice: Evidence From Ethiopian Revenue and Customs Authority Large Tax Payers Office (LTO); Master's Thesis, Addis Ababa University: A.A, Ethiopia

Tait, A. (1988) Value Added Tax: International Practice and Problems, IMF, Washington DC

Tesfaye, B. (2018),tax audit in Oromia Revenue Authority: Practices and Challenges, Addis Ababa: A Thesis, Addis Ababa University: Addis Ababa, Ethiopia.

Thomson, R. (2008), Strengthening Risk Management and Audit Strategies to Improve Compliance,Paper presented at Caribbean Organization of Tax Administration (COTA) General Assembly, July 2008, CARTAC, Belize, available at, <www.cartac.org/ COTA/ Paper/Strengthening/Risk/Management/Final.pdf >, accessed on March 2020.

World Bank (2011), Risk based tax audits: Approaches and Country Experiences/World bank, Washington DC, USA.

Yesegat, W (2008), Value added tax withholding in Ethiopia: Implications for revenue performance and refund, paper presented at a symposium on VAT in developing countries: Policy, law and practice, Pretoria, South Africa, 18-21 October 2016 